\title{
IGNACIO PUSALGAS, UN MÉDICO ROMÁNTICO DEL SIGLO XIX
}

\section{Armando García González}

\author{
Historiador de la Ciencia
}

\section{RESUMEN}

Ciencia, historia y literatura están presentes en la vida y obra de Ignacio Pusalgas. Doctor en Medicina, en 1832, enseñó por tres décadas en la Facultad de Medicina de la Universidad de Barcelona. Sin embargo, es un desconocido prácticamente para la mayoría de la gente. Este artículo analiza algunos aspectos de su pensamiento científico y cómo enlazó estos temas: moral, religión, novela, higiene, anatomía, epidemia, etc.

PALABRAS CLAVE: anatomía, higiene, Ignacio Pusalgas, siglo XIX.

\section{SUMMARY}

Science, history and literature are presents in the life and works of Ignacio Pusalgas. Doctor in medicine, in 1832, he taught anatomy by three decades in the Faculty of Medicine of Barcelona's University. However, he is practically unknown for the most of people. This articule anayize some aspects of his cientific thought, and how he links these themes: moral, religion, novel, hygiene, anatomy, epidemic, etc.

KEY WORDS: anatomy, hygiene, Ignacio Pusalgas, $19^{\text {th }}$ century.

No tan conocido como debiera, el médico y literato barcelonés Ignacio Miguel Pusalgas y Guerris (1790-1874) se inserta dentro de la corriente romántica decimonónica de galenos ilustrados que tuvo diversos cultivadores, tanto en España como en otras naciones europeas y americanas. Un breve resumen de sus títulos y notas que él mismo consigna en varios de sus trabajos, revelan que estudió en el seminario de Barcelona. Más tarde se doctoró en Medicina y Cirugía en 1832. Fue conservador, preparador y director del Museo anatómico de la Facultad de Medicina de la Universidad de dicha ciudad y catedrático sustituto de la Escuela de Botánica y Agricultura de la Junta de Comercio de Cataluña. Socio Correspondiente de la Academia Médico Quirúrgica de esa misma ciudad, y de Mérito del Instituto Médico Valenciano, Auxiliar de la Cátedra de Osteología y Disección, Presidente Honorario del Instituto Escolar Médico de 
Barcelona, Socio Titular de la Asociación Escolar de la misma, y autor y traductor de varias obras científicas, históricas y literarias.

Que no es un total desconocido, se evidencia entre otras cosas en la segunda edición, hecha en Barcelona en 1992 de uno de sus trabajos sobre embalsamamiento, que data de 1861, y en 1988, de su novela El Nigromántico Mexicano, publicada originalmente ciento cincuenta años antes. Además de estas obras, Pusalgas dio a la imprenta otras, de carácter literario, histórico, anatómico y médico, casi enteramente aparecidas en su ciudad natal. Esta última comprende varios tratados de historia y enseñanza de la medicina, de la anatomía, de la higiene y de su labor como disector anatómico, que incluía los gabinetes y museos dedicados a esta especialidad, así como las técnicas de preparación de piezas anatómicas, embalsamamiento y otras cuestiones. Sus trabajos más extensos en el ámbito científico fueron el Manual de higiene: arreglado según la doctrina de Sir John Sinclair (1831), los Principios didácticos de materia médica externa, con un apéndice de aguas medicinales más concurridas de Cataluña (1834) y la Historia compendiada de la medicina (1836). Las tres obras ${ }^{1}$ pensadas con fines educativos, extractadas de diversos autores, en su mayoría franceses. Para no desbordar este artículo, nos ocuparemos sólo de algunos aspectos, teniendo en mente la realización de un trabajo mayor sobre el pensamiento de nuestro biografiado.

Como ya se adelantó, Pusalgas estudió en el Colegio Médico de Barcelona, fundado en 1760 por Pedro Virgili. La institución poseía un hermoso anfiteatro anatómico, donde se realizaban disecciones, pues desde 1764 sus estatutos recogían que tanto la anatomía como las enfermedades quirúrgicas, es decir, la comprobación anatomopatológica, debían ser explicadas en el cadáver. En el Museo de este colegio existían instrumentos de cirugía, aparatos de física y reproducciones de piezas anatómicas, que se empleaban en la enseñanza. Entre éstas estaban algunas obras realizadas en cera por el italiano José Chiappi que, según Usandizaga, solicitó la reválida de licenciado en 1824, entregando unas piezas anatómicas a cambio de las cantidades que tenía que abonar, por carecer de dinero, todavía conservadas en la Facultad de Medicina².

En distintos trabajos, Pusalgas hará referencia en varias ocasiones a estas obras de Chiappi. Todo parece indicar que por los años de 1817-1821 éste estaba

1 Pusalgas, I. (1836), Principios didácticos de materia médica esterna, con un apéndice de aguas mineromedicinales más concurridas en Cataluña, Barcelona, Imprenta de Ramón Martín Indar; PUSALGAS, I. (1836), Historia compendiada de la medicina, Barcelona, Imprenta de José Tauló. Sobre higiene, ver nota 18.

2 Usandizaga, M. (1956), Historia del Real Colegio de Cirugía de Barcelona (17601843), Barcelona, p. 68. 
en La Habana, junto con otro hermano. En dicha ciudad, la Sociedad Económica propuso - mediante el Intendente Alejandro Ramírez- comprar la colección de piezas de cera de Chiappi, que debía entregar con otras más, destinadas al Museo Anatómico de La Habana, que no se fundaría hasta 1823. Los italianos trabajaron dieciocho meses, pero la cantidad fijada en 18.000 pesos pareció excesiva a la Sociedad. Según un periódico de la época, Chiappi, indignado, la destruyó ${ }^{3}$. Piezas anatómicas en cera serían fabricadas también por el médico español José de Benjumeda y el cirujano cubano Nicolás J. Gutiérrez, algunas de las cuales todavía se conservan. De todos modos ésta era la tónica de la época, el Museo del Real Colegio de San Carlos de Madrid estaba muy enriquecido con figuras de cera anatómicas, obra del artista Franchesqui, discípulo de Fontana.

En el Colegio de Barcelona, Pusalgas leyó, el 16 de marzo de 1833, una disertación cuyo título en latín fue Num dentur differentiae et quanum sint inter et neuralgis ${ }^{4}$. Pero la vida del Colegio estaría limitada y en 1843, pasaría a ser la Facultad de Medicina, si bien esta permanecería en el mismo edificio hasta 1906. Así que allí trabajó el médico barcelonés hasta su jubilación.

\section{LA ENSEÑANZA DE LA ANATOMÍA}

A cargo de los trabajos anatómicos de la Facultad Médica de la Universidad Literaria de Barcelona y como Auxiliar de la Cátedra de Osteología y Disección, Pusalgas impartió clases y produjo discursos tanto sobre la anatomía como sobre sus métodos de conservación, disección y embalsamamiento, o sobre los museos de anatomía. Algunos de ellos fueron publicados. Por ejemplo, el leído a sus alumnos el primer día de los Ejercicios osteológicos y de disección en el curso de 1860 a $1861{ }^{5}$. En él, explica la importancia de la osteología para saber cómo curar luxaciones y fracturas, remontándose a la escuela de Alejandría, donde se enseñaba a los discípulos a procurarse un esqueleto, para conocer la estructura del cuerpo humano y llevar a la práctica las operaciones quirúrgicas. Igualmente se le encomendaba en el año 1559 el estudio de los huesos a la Facultad de Medicina de Barcelona.

A medida que las disecciones se generalizaban entre los profesores, la cirugía también avanzaba, siendo los grandes operadores, siempre excelentes anatómi-

3 Anónimo (1820-1821), El tío Bartolo, 53, p. 21. Cfr. VAlero, M. y García, A. (1999), «Ciencia y coleccionismo en Cuba durante el siglo XIX», Asclepio, 51, (1), pp, 205-226.

4 UsANDiZAGA (1956), p. 235.

5 Pusalgas, I. (1861), Breve discurso sobre la importancia de la anatomía descriptiva teórico- práctica (principalmente para la Medicina), y su historia, Barcelona, José Tauló. 
cos prácticos. La anatomía patológica no hubiera progresado sin el estudio preciso de la descripción teórico-práctica. En ese sentido destaca la importancia del estudio de la anatomía de los órganos para conocer sus funciones, del mismo modo que sin la anatomía serían reglas rutinarias, la educación física y moral, y las reglas higiénicas dirigidas a conservar la salud del alma y del cuerpo.

De acuerdo con sus opiniones religiosas, ya comentadas, ve al hombre como el primer eslabón de la cadena de los seres, preeminencia dada por el Creador, de la misma manera que los estudios zoológicos descansan en el hombre como tipo de todos los seres vivientes, citando al respecto a Buffon y Linneo.

La anatomía es importante asimismo para el estudio de las Bellas Artes, pero sería más provechosa si se obligase a los alumnos a estudiarla en los anfiteatros anatómicos, porque la disciplina no se aprende sólo con libros, ni con la enseñanza verbal del maestro, sino que se precisa «leer sobre el mismo cadáver» —es decir, en su estructura-, situación, figura, color y funciones de lo órganos que componen la «hermosa fábrica de la criatura hecha a imagen de Dios».

Las láminas y las piezas artificiales sólo sirven como auxiliares para recordar lo aprendido ya en el cadáver. Aquí, se apoya en el criterio de su antecesor, Francisco Puig, de que las figuras artificiales engañan y muestran defectos que no se presentan en el original, por lo que es menester el estudio director de la naturaleza.

Pusalgas, como el también catalán Mariano Cubí y Soler, al que cita aquí, funde la frenología de Franz Gall, la fisiognomía de Karl Lavater, con el estudio de la anatomía y las cualidades del alma. Por eso asegura que el médico, el naturalista y el jurisconsulto son incapaces de comprender, sin la anatomía descriptiva teórico-práctica, las teorías de esos autores. El saber la anatomía de la cara y el cuadro del alma, o lo que es lo mismo, sus expresiones y pasiones servían, por ejemplo, para obtener la confesión de un crimen oculto «entre las dobleces del corazón de un acusado». Como reflejaba Alibert en su Tratado sobre las pasiones. Estas ideas no eran privativas de Pusalgas, la frenología había sido defendida por diversos médicos franceses, como Broussais, y en España por otros anatomistas, entre ellos Agapito Zuriaga, quien también conciliaba las ideas de Gall y de Lavater con el sentimiento religioso ${ }^{6}$.

Después de hacer un repaso histórico de la disciplina, desde los tiempos antiguos, donde no faltan las opiniones y trabajos de Empédocles, Demócrito, Heráclito, Anaxágoras, los creadores de la escuela de Alejandría, Herófilo y

6 Zuriaga, A. (1838), Compendio de Anatomía General y Descriptiva, Valencia, Oficina de López, 2 t. Véase también AREChAGA, J. (1977), La anatomía española en la primera mitad del siglo XIX, Granada, Universidad de Granada, pp. 105-106. 
Erasístrato, los inevitables Hipócrates, Galeno y Vesalio, así como los médicos árabes, Pusalgas llega a los siglo xv y xvi, señalando algunos aspectos puntuales en naciones europeas como Italia y Francia. En el caso de España, ésta yacía en el abandono y la indiferencia, no contando con ningún anfiteatro ni museo anatómico hasta 1477, con el reinado de los católicos Fernando e Isabel. En las universidades la anatomía se enseñaba sólo con tablas iconográficas más o menos exactas. En el año de 1486 se consignó que el Gobierno concediese cadáveres para efectuar dicha enseñanza, que debían ser inspeccionados, según señalaba el Código respectivo, so pena de multa de mil sueldos.

Pusalgas ignoraba - por lo menos no lo menciona - que mucho antes, en 1402, Martín I había concedido a la Universidad de Barcelona permiso para realizar prácticas anatómicas con cadáveres. Pasa rápidamente al siglo XVI, donde expresa que en el año de 1549, bajo el reinado de Felipe II, el médico aragonés Tabar, catedrático de Prima en Zaragoza, construyó estatuas anatómicas de seda con movimiento, que fueron muy celebradas, por lo que el rey le eligió para médico de Cámara.

En los estatutos de 1638 del Colegio de Medicina de Cataluña se recogía la existencia de una cátedra de anatomía, impartiéndose doce lecciones anuales de disección práctica que abarcaban las preparaciones del cuerpo humano. Las universidades de Salamanca y Medina también se hicieron famosas en el arte de diseccionar, añade Pusalgas sin referir, las muy importantes que fueron además las de Valencia y Alcalá. Entra el siglo XVIII, con la creación del real Colegio de Cádiz en 1737, por Fernando VI, y destaca asimismo el hermoso anfiteatro de la Facultad de Barcelona - antes Real Colegio de Cirugía Médica-, debido a la propuesta que hizo al rey Carlos III, Pedro Virgili, cuyo busto presidía las lecciones de anatomía. Anfiteatro que había dado a la medicina española célebres profesores, y elogios del ministro de Fomento marqués de Cervera. Carlos IV, sucesor de aquel rey, había mandado a levantar los anfiteatros de Santiago y de Burgos. Fernando VII, con los mismos sentimientos, había creado los de Málaga y Zaragoza. Y más tarde, Isabel II había confirmado la protección a la anatomía teórico-práctica en ciudades como Barcelona, Madrid, Granada, Sevilla, Santiago, Valencia y Valladolid ${ }^{7}$.

7 Sobre la medicina en algunas de estas universidades, véase PESET, J. L. (1968), «La enseñanza de la Medicina en España durante el siglo XIX», Medicina Española, 59, 60 y 63; PESET, J. L. (1971), «La enseñanza de la medicina en la Universidad de Salamanca durante el reinado de Carlos IV (1788-1808)», Asclepio, vol. 23, pp. 289-298; LÓPEZ PIÑERO, J. M. (1971), «La contribución de las generaciones intermedias al saber anatómico en la España en 
De ese modo, en todas las facultades médicas de España, mediante instrucciones y reglamentos se regulaba la enseñanza de la anatomía que mostraba su esplendor y comprendía no sólo la explicación histórica y descriptiva, patológica, quirúrgica y topográfica, sino que se complementaba con lecciones y ejercicios osteológicos y de disección, necroscopias, vivisecciones, preparaciones y conservaciones anatómicas, así como con la formación de piezas artificiales plásticas, que incrementaban las colecciones de museos y gabinetes.

En esa línea menciona el apoyo del Gobierno en ese año de 1861 al doctor Pedro González de Velasco ${ }^{8}$, cuyas colecciones en materia plástica, trabajadas por él, eran importantes para la enseñanza de la anatomía descriptiva, quirúrgica y patológica. Velasco estará presente también en otros discursos y trabajos de Pusalgas, como una figura relevante, por ejemplo, en el discurso de apertura del curso de 1871, que comentamos más adelante.

Después de subrayar la importancia de las descripciones y demostraciones anatómicas - que eran públicas y gratuitas - para naturalistas, escultores, estatuarios y pintores y hasta para los religiosos - como Fray Luis de Granada que había publicado una Descripción de la fábrica del cuerpo humano-, Pusalgas dice a sus alumnos que pueden contar para los estudios teóricoprácticos en el cuerpo humano, suficientes cadáveres, algo con lo que no tienen a su disposición abundantemente las demás naciones. Y finaliza con recomendaciones éticas a los discípulos para que practiquen con piezas y modelos anatómicos, antes de utilizar el escalpelo, para no profanar inútilmente esos cadáveres, sin provecho para la ciencia. Y aquí, para conciliar su labor con su ideología católica, asegura que la religión y la moral permiten anatomizar el cuerpo humano difunto, pero sólo con laudable ánimo de engrandecer la medicina y las ciencias naturales. Todo lo cual explica que al comienzo de esta memoria refiera las opiniones opuestas que tenían Chateubriand, quien veía la autopsia como una operación sacrílega, y Marquis para quien estudiar los cadáveres era un medio de socorrer a los vivos, enseñándole con la muerte los secretos de la vida.

En el desarrollo este trabajo, Pusalgas menciona diversos anatómicos más o menos célebres, como Swammerdam, Sabatier, Bonells, Lacaba, Pedro Dionis, Maygrier, Croveilhier y Laud, cuyo Manual anatómico del disector, tradujo al español Carlos Quijano, y servía de texto en la Facultad de Medicina de Bar-

\footnotetext{
el siglo XIX», Asclepio, 23, PP. 95-130; DANÓN, J. (coord.), La enseñanza de la medicina en la universidad española, Fundación Uriach, Colección Histórica de Ciencias de la Salud.

8 Sobre este autor véase PUIG-SAMPER, M. A. (1982), «El doctor Pedro González de Velasco y la antropología española en el siglo XIX», Asclepio, 34, pp. 327-337.
} 
celona. Eso no obsta para que el famoso libro de Bonells y Lacaba continuase empleándose de diversos modos 9 .

Para el curso de 1869 a 1870, Pusalgas elaboró y publicó otro discurso a las lecciones de anatomía práctica de la Facultad de Medicina de la Universidad de Barcelona $^{10}$. Igualmente dio a la imprenta, en 1871, unos Preliminares a los ejercicios de osteología y disección, publicado como el anterior en su ciudad natal ${ }^{11}$. En este discurso hace un rápido recorrido por los principales cultivadores de la anatomía y las disecciones, desde la escuela de Alejandría, pasando por Galeno y los árabes, el siglo x hasta Vesalio, Falopio, Sylvio, Wislow, así como un gran número de médicos y naturalistas de los siglos XVIII y XIX que sólo nombra: Buffon, Maygrier, Goethe, Galvani, Soemmering, Dupuytren, Saint-Hilaire, Flourens, Bichat, Velpeau, Chiappi. Entre los que destaca los españoles Gimbernat, Lacaba, Velasco, Losada, Giné, Puig, Fernando del Valle, remontándose a Servet y a Laguna, entre otros, para destacar los progresos científicos en los que España no queda a la zaga. Lo que justifica la defensa que hace Pusalgas de la ciencia española, expresando que las doctrinas nacionales son más sencillas y quizás más profundas y basadas en experimentos imparciales, carentes de «fraseología impertinente», como a su juicio se evidencia en el Tratado de Anatomía general, de Bonells y Lacaba.

Resulta curiosa su recomendación a los alumnos de que estudien la anatomía por un solo autor, para que no se sientan perplejos ante las mil opiniones o doctrinas diversas que se hallaban en los escritos extensos y enciclopedias, textos a los que debían acceder cuando pasaran los años y se sintiesen fuertes en los principios anatómicos. Sólo entonces debían estudiar la anatomía comparada y la filosófica. Medida que se justificaba por la opinión del médico barcelonés, pero que desde el punto de vista del conocimiento, hoy no veríamos muy recomendable. Si bien, desde el punto de vista pedagógico es acertado comenzar por un manual sencillo e ir más tarde a lo más complejo. Igualmente adecuada es su exhortación a los alumnos para que consulten a sus maestros todas las dificultades encontradas en las lecciones prácticas.

Además de recomendar textos y autores (entre los que estaban los manuales de Lacaba y de Pedro Mata), Pusalgas proponía que los educandos conta-

9 Bonells, J.; LaCABA, I. (1796-1800), Curso completo de Anatomía del cuerpo humano, Madrid, 5 vols. (2a . ed. Madrid, 1820, 5 vols.).

10 Pusalgas, I. (1869), Discurso preliminar a las lecciones de anatomía práctica en la Facultad de Medicina de la universidad literaria de Barcelona. Curso académico de 1869 a 1870, Barcelona, Establecimiento Tipográfico de Jaime Jepús.

11 Pusalgas, I. (1871), Preliminares a los ejercicios de osteología y disección, Barcelona, Establecimiento Tipográfico de Jaime Jepús. 
sen con un esqueleto completo para el estudio de los huesos o en su defecto de láminas y piezas artificiales de museo que podían reemplazar en parte las naturales. «Por mi parte procuraré, en esta sala práctica, todas las piezas de cadáveres que se puedan disponer, para que mis alumnos trabajen sus respectivas demostraciones...»». Los discípulos debían comenzar sus respuestas por la nomenclatura, sinonimia, y etimología; después, siguiendo un orden lógico, descripción, antecedentes, parte externa, interna, etc. La propuesta de Pusalgas estaba en concordancia con los treinta ejercicios osteológicos que la ley de Instrucción pública orientaba antes de pasar al estudio de las partes blandas del cuerpo, o lo que era la mismo, la parte práctica en el cadáver.

En ese sentido, pasa a ocuparse del arte de disecar, mencionando los instrumentos a emplear, el modo de utilizarlos y de acceder a las distintas regiones y sistemas del cuerpo, donde señala los órganos que encontrará el alumno, así como diversas recomendaciones pedagógicas y de conservación de los cadáveres y de sus partes.

No faltan aquí, como en otros trabajos suyos las referencias mecanicistas, como cuando recomienda el uso del microscopio binocular a los alumnos, para observar «los elementos físicos de que se componen tantos órganos y aparatos de nuestra complicada y frágil máquina». Tampoco, dada su filiación religiosa, otras reflexiones filosóficas, donde se proyecta en contra del materialismo, que hace al mundo un «caos de monstruosidades», y de las doctrinas erradas del ateísmo, a las que estima «aberraciones del cerebro del hombre». Reflexiones que recomienda hagan los alumnos a medida que estudian el cuerpo humano.

Por último, pide a los discípulos que redoblen sus esfuerzos para aprovechar los dos tercios del curso que quedan, ya que el inicio del mismo se había pospuesto para enero de 1871 (debiendo empezar en octubre de 1870) debido a la epidemia de fiebre amarilla o vómito negro, desencadenada en Barcelona. Enfermedad que en 1821 se había cobrado diez mil víctimas en esta ciudad.

Pusalgas por su parte se comprometía a hacerles fáciles y comprensibles las lecciones anatómicas y procurar — si las preparaciones y piezas anatómicas no eran accesibles a todos los alumnos - que pudieran estudiarlas en iconografías y modelos de anatomía clásica, como los presentadas por el Dr. Auzoux.

Un juego de piezas desmontables de cartón, de anatomía humana y animal, también denominada colección clásica del doctor Auzoux, estaba entre las que servían para la enseñanza de esa disciplina en el Museo Anatómico de la Habana, fundado en 1823. Aquí estuvieron - ignoramos desde cuando- hasta 1863, en que las colecciones pasaron al museo de la Universidad de la Habana, con las 
reformas realizadas en este año en esa institución. Piezas de cera, instrumental de cirugía y obstetricia y la colección de Auzoux estaban entre ellas ${ }^{12}$.

\section{Museos y gabinEtes de ANATOMÍA. SuS PREPARACIONES}

La experiencia práctica adquirida por Pusalgas en la preparación de piezas naturales en relación con los museos anatómicos, la volcó en algunos trabajos escritos y publicados en los años sesenta. En uno de ellos ${ }^{13}$, destacó que el mérito y la utilidad de los museos anatómicos no dependía del mayor número de piezas preparadas y conservadas, sino que las colecciones fuesen bien escogidas y estuviesen completas para el estudio de la ciencia a que se destinaban. Si bien para la enseñanza de la anatomía descriptiva y topográfica, abundaban todos los años los cadáveres en las salas de disección, no siempre se podía trabajar con ellos por el rigor de la estación y las leyes del Reglamento o porque en ocasiones faltaban las piezas frescas cuando se las necesitaba.

También escaseaban las piezas que se precisaban para explicar cursos sobre anatomía patológica, teratología e incluso fisiología, pues no siempre podían encontrarse, por ejemplo, cráneos y cerebros donde tener una mejor idea del idiotismo congénito, de manías y demencia, de la frenología y de las razas humanas. Sin piezas naturales y artificiales, difícilmente era posible entender la ortopedia, las deformaciones de la columna raquídea, pelvis y extremidades.

Aquí aprovecha la ocasión para demandar indirectamente mejoras para los museos anatómicos, al expresar que las mejores teorías, progresos e inventos científicos procedían de ciudades como Alemania, Inglaterra, Bélgica, Holanda, Rusia, Francia e Italia, que habían organizado museos que eran «dignos templos de la Sabiduría», y estaban abiertos a la juventud estudiosa y al hombre pensador. De esos museos bebían el alumno y el maestro, pues eran bibliotecas de doctrinas prácticas que enseñaban más convincentemente que las demás, ya que eran positivas e indisputables. Y aunque celebra al Gobierno por sus leyes protectoras para poner a España a la altura de otras naciones, critica a los ambiciosos y egoístas que levantan la voz contra las producciones españolas, que ni entienden ni son capaces de imitar. Pero, a pesar de todo, se

12 VALERO y García (1999), p. 215.

13 Pusalgas, I. (1862), Ensayo sobre formación y arreglo de un museo anatómico, orden científico de las piezas naturales y artificiales para el fácil y completo estudio de la organografia humana descriptiva, general, topográfica, quirúrgica y patológica, obstétrica, clínica médica, etc., Barcelona, Imp. de Joaquín Verdagues, Rambla, Frente al Liceo. 
impondría por la fuerza el progreso material y científico. ¿Acaso lo primero que hacían los extranjeros al visitar un país no era ir a los museos? Pero, ¿qué juicio podían hacerse si los encontraba mezquinos y abandonados?

Entre otras cosas, reproduce en su trabajo las Disposiciones del Museo anatómico, o lo que es lo mismo cómo debían ser las salas, los instrumentos para medir la humedad, la temperatura y la presión atmosférica; armarios - coronados estos con bustos de los más célebres médicos españoles, preferentemente anatómicos-- piezas anatómicas en sus secciones, numeradas y con su relación histórica en latín, registradas en un libro, y otro para las visitas, como el de Cirujanos de Londres. Dividía el museo, en: Museo de Anatomía Descriptiva y General, Museo de Anatomía Topográfica y Quirúrgica, Museo de Anatomía Patológica y de Obstetricia, Museo de Enfermedades Exantemáticas y Sifilíticas, Museo de Clínica Médica y una Galería Iconográfica para estampas, pinturas y atlas de figuras anatómicas. Estos museos tenían a su vez secciones correspondientes. Así, el primero tenía: $1^{\text {a }}$ Osteografía, $2^{\text {a }}$ Artografía y Sindesmografía, $3^{\text {a }}$

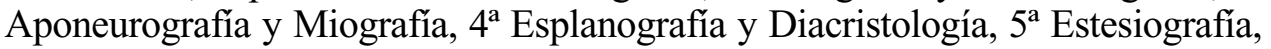
$6^{\mathrm{a}}$ Angiografia, $7^{\mathrm{a}}$ Neurografia y una Sección Adicional para instrumentos, como microscopios, etc. El segundo Museo, contaba con las secciones siguientes: $1^{\text {a }}$ Topográfica, $2^{\mathrm{a}}$ Quirúrgica, y una adicional referente a ortopedia, aparatos, instrumentos quirúrgicos, etc. El tercero, tendría: $1^{\text {a }}$ Patológica, $2^{\mathrm{a}}$ Obstétrica. El cuarto, $1^{\text {a }}$ Exantemáticas, $2^{\text {a }}$ Venéreas.

En todos los casos, Pusalgas asegura que se dispondrán esas piezas según el orden que señalan los programas de estas ciencias, organizados por el Gobierno. Dice además de qué material pueden construirse y hasta obtenerse. Así, por ejemplo, los cráneos de diferentes razas en materia plástica, del museo frenológico de M. Guy, hijo heredero en París. Otras piezas se podían mandar a construir a modo de estatuas plásticas que representen cadáveres, como el que hizo el doctor italiano José Chiappi para el antiguo Colegio de Cirugía Médica de Barcelona, o tomando por modelo la estatua anatómica de la Academia, la de Rafael Mengs o la del joven Eugenio Caudron, dirigida por el doctor Julián Fau. También se podían mandar a construir piezas de cristal y plástico, para representar las enfermedades de los ojos, tomando como modelo los cuadros del museo anatómico de la Universidad Central y el de Barcelona, dirigido por Antonio Gimbernat (Pusalgas poseía dos de esos cuadros donde se representaban las enfermedades de esos órganos y sus operaciones); o siguiendo la colección o museo llamado de Thibert (al parecer copiada o comprada a este francés), que poseía la Universidad central para mostrar las enfermedades de la piel y sifilíticas. También podía servir de modelo sobre estas enfermedades el Atlas de Ricard para la fabricación de piezas artificiales, cuando se careciera del original. 
Pusalgas demandaba además que los armarios del museo de Barcelona, contaran para sus colecciones de Clínica Médica, piezas patológicas naturales y artificiales, cráneos y cerebros de locos, maniáticos y criminales, con retratos, modelos y vaciados de las cabezas de esos individuos. Como era un seguidor de la frenología, recomendaba la compra del gabinete de Guy, donde se vendía una colección de cabezas de material plástico, representando diferentes grados de idiotismo congénito, alienaciones mentales y otros trastornos señalados por Gall y su seguidor Spürzheim. Un museo de vesania era para él «la mejor e inestimable joya» que pudiera poseer la Facultad de Medicina y todo manicomio, pues podría ser de gran utilidad para el estudio de la frenología espiritualista y conocimientos modernos psicológicos (léase psiquiátricos) sobre la locura. Por eso también proponía se reservasen suficientes estantes para colocar en ellos las cabezas artificiales que mostrasen las pasiones y las razas, sin olvidar el modelo con el que Gall y Cubí explicaban las facultades intelectuales, que «suponen conocer en el cráneo humano».

Por esa misma época, Pusalgas redactó un Reglamento ${ }^{14}$ para los departamentos de anatomía y sus museos, que publicó en 1869 , precedido de dos cartas: una de su hijo Ignacio Pusalgas y Alcina - de 30 de noviembre de 1860 - en que le decía haber leído en los periódicos que el gobierno de España acababa de «dar libre la enseñanza en toda su extensión», y animaba a su padre a publicar el citado Reglamento para el buen funcionamiento de esos departamentos y museos, y los adelantos de sus alumnos. Y la respuesta de éste - fechada el 28 de diciembre - donde se quejaba de que (ya por ocuparse de otros asuntos, ya por desinformación de los Ministros de Fomento y Directores de Instrucción Pública) habían transcurrido muchos años sin que la enseñanza de esa disciplina contase con un moderno Reglamento. Si bien se publicó uno, el 20 de agosto de 1830, para los antiguos Colegios de Medicina y Cirugía, así como las Instrucciones, de 5 de enero de 1846, que derogaron el anterior, no cumplían con los cambios que se habían realizado en los planes de la enseñanza médica. De manera que no podían establecerse como ley.

Al decir de Pusalgas, cuando ya estaba en la prensa su trabajo, recibió de su amigo Pedro González de Velasco el proyecto que acababa de publicar sobre la Reorganización de los trabajos y Museos de Anatomía, de Medicina y Cirugía de España. Su larga experiencia al frente del Museo Anatómico de la Facultad Médica de Madrid, y sus muchos viajes al extranjero, le habían

14 Pusalgas, I. (1869), Pensamientos acerca de un Reglamento para los departamentos de anatomía práctica y sus museos anatómicos de las Facultades de Medicina del Reino, Barcelona, Establecimiento Tipográfico de Jaime Jepús Roviralta. 
permitido iniciar los que deseaban los amantes de la gloria de la medicina. Aunque el proyecto y plan de ambos era similar, Pusalgas lo dio a la imprenta, pues consideró que el suyo era más explícito que el de Velasco y además con la intención de que el Gobierno, conociéndolo, diese «un impulso protector a los hasta aquí descuidados trabajos de anatomía práctica».

Muy relacionado con su labor como disector anatómico, Pusalgas tuvo que ocuparse de la conservación de órganos y cuerpos humanos. En un trabajo publicado en 1857, hace una reseña histórica del arte de embalsamar cadáveres y de conservar y preparar piezas anatómicas ${ }^{15}$. En la misma apunta las razones (el amor, el agradecimiento, la vanidad, la superstición) por las cuales la humanidad se ha ocupado de embalsamar cuerpos humanos. De forma romántica y al uso de entonces, dada la repugnancia que tales prácticas producían en diversas personas, aclara que ciencia, religión e higiene no se oponen a la conservación de los cuerpos amados. Y pasa a realizar un rápido recorrido por los pueblos antiguos (egipcios, romanos, griegos, canarios guanches, y en América, Brasil), donde apunta las formas de embalsamar, algunas veces las técnicas e intenciones, y especialmente insiste en la eficiencia - si bien desconocida - de los métodos egipcios para momificar, en relación incluso con los llevados a cabo en Francia, en tiempos anteriores al siglo XIX, que no eran los mejores.

No obstante, ahora, en su siglo, la química moderna y la historia natural aseguraban la momificación por tiempo indefinido. Los métodos modernos eran más sencillos, de base más estable y menos dispendiosos que los de la Edad Media. Entre otras cosas, empleaban muchas plantas odoríferas que favorecían la putrefacción. En ese sentido menciona los trabajos realizados por distintas personalidades francesas, como Boudet, Pelletan, Portal, Alibert, Dupuytren, Beclard, Gannal, Lefebre, Suquet, y otros. De España, se refiere a Orfila que elogia mucho el de Sucquet, conservador-preparador del Museo de la Escuela de París, que usaba cloruro de zinc, percloruro de mercurio o el sulfito de sosa. Según Orfila, estos nuevos procedimientos habían producido una verdadera revolución en los trabajos anatómicos, ya que se podían conservar los cadáveres por un mes, aunque la temperatura fuese elevada. También los médicos Nieto y Serrano, Polin y Simó, del cuerpo de Sanidad Militar, habían logrado perfeccionar el método de Gannal con uno suyo nuevo e inédito.

15 Pusalgas, I. (1857), Reseña histórica del arte de embalsamar los cadáveres, conservar y preparar las piezas anatómicas naturales y artificiales para el estudio y enseñanza de la organización humana normal y patológica, por I. M. P. y G., Barcelona, Imprenta de J. Ribet. 
Como en la época de Pusalgas no se conocían aún los verdaderos agentes de la putrefacción, las causas se buscaban fundamentalmente en las influencias del medio y las reacciones químicas que, por consiguiente, se generaban en los cuerpos orgánicos. Por eso el médico barcelonés arguye que cuando cesa la desconocida fuerza vital y el cuerpo muere, actúan sobre él la humedad, el aire, el calórico, el fluido eléctrico, el magnético y la luz, pero sobre todo los dos primeros, produciéndose la putrefacción. El preparador debía pues buscar para los embalsamamientos, sustancias simples que tuviesen menos afinidades con el oxígeno, el hidrógeno y el azoge que componen el agua y el aire. Incluso usar el menor número posible de sustancias: lo deseable - aunque imposibleera incluso emplear una sola, que tuviese la facultad de combinarse con todas las del cuerpo muerto. De sus experimentos y de los franceses, Pusalgas relaciona las sustancias más adecuadas para estos trabajos, sus ventajas e inconvenientes, y, en algunos casos, el método utilizado para conservarlas.

Son importantes para el estudio y la enseñanza de la anatomía fisiológica y patológica las piezas secas, como las osteológicas y especialmente colecciones de cráneos para el conocimiento de la frenología, de las vesanías, el idiotismo y la criminalidad. Celebra en ese sentido el gabinete de Orfila, y de Dupuytren y el Jardín de plantas de Anatomía comparada de París, así como la rica colección osteológica que se encontraba en la facultad de Medicina de la Universidad central, preparada por Pedro González Velasco, su director entonces; y el gabinete anatómico de la universidad de Barcelona, preparado por Pusalgas, que contenía «un precioso número de huesos humanos en estado normal y patológico». En los museos de Velasco había visto piezas que había logrado endurecer, como unos trozos de cerebro, «tan duros como la madera, cuya recomendación es grande para las momificaciones indefinidas».

Pusalgas explica los métodos para preparar y conservar huesos (maceración, ebullición y blanqueo), así como otras estructuras anatómicas, siguiendo autores como el inglés Swann (preparación de casos sanguíneos), el francés Dumeril, y otros. También subraya la importancia de piezas que imiten a los órganos humanos, como las confeccionadas con materias plásticas, y especialmente el uso de la cera, pudiéndose mezclar con colores minerales y vegetales. Hace un breve recorrido por la historia de la ceroplástica, remitiéndose a griegos y romanos antiguos y dedicándole mayor atención a Italia y Francia, donde menciona autores que realizaron esa admirable labor en relación con la anatomía y con el arte de partear, la obstetricia. Destaca la escuela de Bolonia y de Florencia, en que trabajaron Antonio Gallí con sus célebres piezas sobre el embarazo (distintas fases del feto en el vientre materno), Ferini y otros. En Barcelona, hace referencia a la labor de José Chiappi, doctor en cirugía médica 
del antiguo Colegio de la Facultad de Medicina y estatuario de Roma, que había trabajado para Soler, catedrático de anatomía descriptiva, confeccionando un gran número de piezas de cera de mucho mérito para la enseñanza de la anatomía fisiológica y patológica. En España había que admirar también las colecciones de obstetricia, de nervios y vasos linfáticos del gabinete del antiguo Colegio de San Carlos y ahora facultad de Medicina. Asimismo significa las cinco estatuas de forma natural, en cera, que representan el esqueleto con sus ligamentos; músculos y nervios del gran simpático, piezas que Bonells y Lacaba estimaban tan exactas y primorosas como las del gabinete de Toscana.

La cera permitía representar no solamente las piezas anatómicas naturales, sino aquellas que demostraban diversas patologías, aberraciones, deformidades y males que afligían a la especie humana, como se observaban en distintos gabinetes y museos, como el del Dr. Despine, hijo, que en su establecimiento de aguas termales en Aix, en Saboya, tenía una colección en cera de casos - curados por él - de eritemas nudosos, fracturas, sífilis tuberculosas, tumores escrofulosos y úlceras gangrenosas.

Asimismo, otros materiales, como el cartón piedra, cartón cuero, cartón tela y cartón madera, servían para confeccionar piezas anatómicas. Pusalgas explica las sustancias que componen estos materiales, así como las personalidades y en qué museos se exponían. Por ejemplo, la composición (blanco de España, cola fuerte, pasta de papel y almáciga) que se usó para elaborar las piezas anatómicas del Museo de M. Thibert en París; de cuyo Museo la Facultad de Madrid había comprado muchos cuadros, representando enfermedades sifilíticas y cutáneas, con que formó una colección denominada del gabinete Thibert. El vidrio o cristal también era útil para representar figuras o porciones como los ojos y sus enfermedades. Al respecto asegura que en el museo anatómico de la Facultad de Medicina de Barcelona existía un hermoso cuadro que contenía 70 enfermedades oculares, imitadas en cristal, observadas en el Hospital de Santa Cruz por el doctor Antonio de Gimbernat, trabajadas por el artista catalán José Balls, bajo la dirección de aquel profesor.

Como la visión de la naturaleza que se trataba de representar en estas piezas anatómicas, llegaban al punto de reflejar sentimientos (lágrimas, dolor), como se concebía en la época, Pusalgas manifestaba que el preparadorconservador de las mismas debía poseer ciencia, arte e ingenio. Así, para imitar las maravillas del Creador, no había necesidad de visitar otros países, con arte e ingenio se podían fabricar las razas humanas, sus cráneos que reflejen las opiniones de Camper, sobre el ángulo facial que establece los distintos grados de inteligencia, la frenología y craneoscopía de Gall donde avanzaba «su decantada doctrina de las facultades intelectuales» y las variadas fisionomías del rostro con que Lavater pintaba las pasiones humanas. 
Sin piezas artificiales —opinaba Pusalgas - era imposible dar cursos completos sobre el desarrollo del feto en el claustro materno durante el embarazo, la circulación de la sangre hasta sus más finas ramificaciones, huesos membranas, cartílagos, pero también los casos teratológicos en animales y plantas y las múltiples enfermedades.

Concluye quejándose de que en España no son muchos los aficionados al arte de las preparaciones anatómicas y desea que los médicos españoles le tomasen cariño para que los gabinetes nacionales estuviesen bien provistos, sin tener que «mendigar de manos extranjeras, que tan poco honor hacen al genio español».

En otra memoria, publicada en 1861, explica las técnicas a aplicar con el cadáver (cortes, sustancias químicas, urnas o ataúdes para las momias, ropas que se usan) a fin de conservar éste por tiempo definido o indefinido ${ }^{16}$. Aquí destaca la importancia de que el trabajo lo realice una mano experta, como la del médico preparador, de modo que pueda asegurar una operación adecuada y una excelente labor artística en la presentación del cadáver. De ello, depende su buena reputación. Debe, pues estar al corriente de los métodos de conservación de piezas anatómicas y de los estudios químicos en relación con ellos, no sólo para la preparación de piezas para gabinetes y museos, sino también cuando se presenta la ocasión de embalsamar el cuerpo de alguna persona de alto rango en la sociedad.

Que este trabajo está pensado para médicos y cirujanos, no cabe duda. Pusalgas dice que lo publica con el deseo de ser útil a sus compañeros de la Facultad. No puede menos que hacer alusión, aquí como en otros trabajos, a su labor en dicha Facultad, y en este caso a su método para conservar piezas anatómicas, que considera, sin mérito ni vanidad, por «el más seguro de entre los muchos publicados y que hemos ensayado».

\section{ANATOMÍA Y FISIOLOGÍA DE LA MUJER EN RELACIÓN CON EL TRABAJO}

La anatomía y la fisiología de la mujer en relación con los trabajos a que podía dedicarse ésta, también fue objeto de estudio del médico barcelonés,

16 Pusalgas, I. (1861), Métodos de embalsamamiento por tiempo definido e indefinido, mutilando lo menos posible los órganos del cadáver, Barcelona, Imp. de José Tauló; (1992), Métodos de embalsamamiento, Librería «París Valencia», D. L. Reproducción facsímil de la edición de Barcelona, Imp. de José Tauló, 1861. 
como se observa en una memoria suya ${ }^{17}$, que fuera leída parcialmente en marzo de 1873 en el Anfiteatro anatómico de la Facultad de Medicina de su ciudad, pero que fue «interrumpida por causas ajenas del autor». Suponemos que por lo controvertido del tema para la moral de la época.

En ella, Pusalgas congenia las cualidades de la mujer con el Génesis bíblico, subrayando las características físicas que la diferencian del hombre en cuanto a delicadeza, armonía, belleza con descripciones que a veces rondan cierto fino erotismo o morbidez. Si bien alude también a las «mujeres varoniles o atletas», como las heroínas Juan de Arco y Carlota Corday y en España Mariana Pineda, Agustina Zaragoza, de Barcelona, Eulalia, de esta misma ciudad, la Eulalia de Mérida, y otras mujeres «casi superiores a los hombres en pujanza y osadía» que se destacan en el Vancour, las germanas citadas por Virey (Historia Natural), y otras. «Pero esto no quita, que nuestras mujeres en general sean de una constitución delicada, cuya delicadeza y debilidad debían ser respetadas y puestas bajo el amparo del hombre».

Pero no siempre ni en todos los países la mujer había sido tratada bien, sino al contrario, considerada como esclava, (por los mahometanos y los hombres de la selva), negándosele hasta el alma inmortal, como hacían los rabinos. La llegada de Jesucristo la había restituido a ser la compañera del hombre, no su propiedad, dice Pusalgas.

$\mathrm{Su}$ análisis se torna determinista al referirse al carácter o temperamento de la mujer (femenino con tinte de sanguíneo, pero que cambia con la edad, volviéndose varonil a los 45 ó 50 años cuando cesa el flujo catamenial), o al asegurar que el estado de preñez, el parto, y «el predominio que tiene su matriz sobre su naturaleza», hacen que la mujer no pueda libremente dedicarse a la mayor parte de las artes, propias del hombre. Por eso recomienda que no realice el trabajo en los telares, carpintería, cerrajería y albañilería, propios de otro vigor y conformación corporal. Además, como el influjo de la matriz sobre el sistema nervioso, produce en la mujer cambios físicos y morales, provocando en ella el histerismo, el clavo histérico y la barra epigástrica, la vuelve taciturna, triste y desdeñosa hasta con quienes ama. «¿Cómo pues la mujer puede dedicarse al comercio en gran escala, cuando es tan común el engaño y la mala fe?».

17 Pusalgas, I. (1873), Los aparatos y sistemas anatómicos del cuerpo de la muger y sus funciones fisiológicas, ¿permiten que se ocupe, como el hombre, á todas las artes y a todas las ciencias? Dedicado a las damas españolas por I. P. y G., Barcelona, Establecimiento Tipográfico de Jaime Jepús Roviralta. 
El determinismo se refleja asimismo en la creencia de Pusalgas de que la mujer posee más sensibilidad e irritabilidad, dadas por el mayor desarrollo del sistema nervioso, que el hombre; si bien asegura que aunque la fisiología no se ha pronunciado sobre la diferencia de estructura de la masa encefálica de la mujer con la del hombre, en ella dominan las facultades afectivas, mientras que en el segundo dominan las intelectuales. Una cita sacada de Virey, le sirve para fundamentar que «el hombre obra y piensa y la mujer ama, cuida y halaga». Si bien, Pusalgas se apresura a reconocer que la educación física, moral e intelectual modifican mucho estas preponderancias en ambos sexos.

Y pone distintos ejemplos de mujeres que se destacan como poetisas, filósofas, científicas, para lo cual se apoya también en la frenología de Gall y la fisiognomía de Lavater, que muestran las mismas disposiciones de la conducta, el carácter y la capacidad de la mujer, al igual que en el hombre. Pero el asunto estriba en que no realiza el ejercicio de esas capacidades, pues la educación de la mujer es nimia y defectuosa. En ese sentido, Pusalgas se proyectó a favor de la educación de la mujer, echando fueras las trabas que le impedían dedicarse a la ciencia y a las artes. La carta que coloca como anexo a su trabajo, de la Dirección General de Instrucción Pública, es bastante elocuente de los prejuicios - aunque no es este el espíritu que anima al médico barcelonés- que existían todavía en el ámbito general en cuanto a la libre incorporación de la mujer a la enseñanza. Pues, aunque se dice que la ley no prohibe que se conceda al permiso a una tal $\mathrm{D}^{\mathrm{a}} \mathrm{N}$. N. para que curse estudios, se hacen notar «los inconvenientes, que dado el estado de nuestras costumbres, podría ocasionar la reunión de ambos sexos en las clases, no obstante el indisputable derecho que a la instrucción tiene la mujer del que pueda usar, estudiando privadamente y dando a sus estudios validez académica por los medios marcados en la legislación vigente».

\section{LA HIGIENE}

El primer trabajo de Pusalgas, un manual de higiene ${ }^{18}$ debió comenzarlo en su etapa de estudiante, y se publicó en 1831, un año antes de licenciarse en

18 Pusalgas, I. (1831), Manual de higiene: arreglado según la doctrina de Sir John Sinclair, Barcelona, Rubió; (1839), Compendio de higiene ó arte de conservar la salud; redactado de las obras de sir John Sinclair por D. Ignacio Pusalgas $\left(2^{a}\right.$ ed.. corr. y aum. con un índice alfabético de las sustancias alimenticias con sus nombres sistemáticos), Barcelona, libr. de José Solá; Pusalgas, I. (1843), Compendio de Higiene o Arte de conservar la salud redactado de varias obras, mayormente de John Sinclair, Barcelona, Imprenta de Indar, $3^{\mathrm{a}}$. ed. 
medicina y cirugía. Es una obra sintética, resumida de Sir John Sinclair, incluso con algunas de sus partes traducidas literalmente, como el propio $\mathrm{Pu}-$ salgas reconoce, pues no pretendía sino presentar tales lecciones sin profusión y en menor tiempo, a fin de que se pudiera aprender lo vasto de la higiene en un plazo de dos o tres meses. Esta obra, sería corregida y aumentada considerablemente por el autor en una segunda edición, también publicada en Barcelona, en 1839, añadiéndole, entre otras cosas, un índice alfabético de las sustancias alimenticias con sus nombres sistemáticos.

Como es lógico, está redactada al estilo y con los conceptos aún predominantes en la época — aunque daten de siglos atrás - sobre la herencia del talento y a enfermar, el cuerpo como máquina (mecanicismo), el efecto deletéreo de los miasmas, la acción excesiva de los climas, las enfermedades acordes con los temperamentos, y otras.

Así, por ejemplo, se atribuye la herencia del talento a la herencia materna. La herencia o disposición a enfermar, reconocida desde Hipócrates como verídica y aun «aconsejado a los legisladores el precepto de enlazar dos personas de vida valetudinaria, o invadida de alguna enfermedad». Esto no quiere decir que una mala constitución no pueda ser susceptible de mejorar a lo largo de una serie de generaciones. Si la madre es fuerte y bien constitucionada es difícil que tenga hijos débiles y enfermizos, con lo cual cita a Bacon para quien los infantes participaban más de la constitución de la madre que del padre. De igual forma errónea expresa que las enfermedades hereditarias no se transmiten de padres a hijos, si estos han nacido antes de manifestarse aquéllas. Es decir, si la epilepsia por ejemplo, se evidencia a los cuarenta años en un padre, los hijos nacidos antes de esa edad, estarán exentos de ese mal; mientras que los nacidos después de esa edad, tendrán la disposición a enfermar.

Desde luego, aún no se conocían los trabajos de Mendel y sus seguidores, que no ocurriría sino a partir del redescubrimiento en 1900 de las leyes del monje checo, y ni siquiera Darwin había escrito sus famosos trabajo sobre el Origen de las especies (1859), donde se refería a ciertos caracteres hereditarios que se presentan en los hijos a la misma edad que en los padres.

La longevidad también es atribuible por Sinclair-Pusalgas a la herencia, aunque coadyuvan otros factores, como nacer en tiempo (si no se precisa redoblar las precauciones higiénicas), ser hijo único (pues se considera a los embarazos múltiples como si fueran embarazos prematuros, ya que la mujer está destinada a tener un sólo hijo a la vez), nacimiento lento y gradual (se cita aquí a Hufeland), una buena constitución física, pasiones moderadas y un temperamento alegre sanguíneo, con un ligero tinte de flemático, que parece ser, a su juicio, el mejor. Aunque Galeno manifiesta, que con cuidado y vigilancia, se puede modificar el temperamento y robustecer la constitución. 
También la longevidad es favorecida por la forma regular y proporcional de todos los órganos. Aquí aboga por la doctrina de Hufeland, describiendo el aspecto físico y moral de las persona destinada a vivir más tiempo: pelo rubio más que bruno, talla mediana, carácter sereno, activo, susceptible de alegría, amor y esperanza, pero insensible a los impulsos del odio, la cólera y la avaricia; que ama la ocupación, meditar con calma, no ambicionar honores ni riquezas y estar siempre contento con su suerte.

La duración de la vida está relacionada pues con el influjo de los talentos y de las pasiones. Si está controlado el talento, está bien, pero si no, puede ser una vía para enfermar. La visión que se desarrolla es la romántica que concibe el talento acompañado por lo regular de defectos corporales, o reñido con la belleza y la elegancia; determinismo físico que le hace expresar que la mayor parte de los hombres gruesos y de constitución en apariencia fuerte y saludable, tienen por lo regular limitado talento. En las pasiones, son esencialmente perjudiciales el temor y la nostalgia, que no producen de forma directa tal o más cual enfermedad, pero sí trastornan los procesos fisiológicos (sueño, digestión), de modo que Bacon recomienda no comer o dormir luego de experimentar violentas «afecciones del alma».

Se admite también determinismo sexual, al asegurar que las mujeres viven más por su constitución y por estar menos expuestas a guerras, naufragios, enfermedades de la demasiada libertad. Parece que las mujeres son más débiles, delicadas y sedentarias, pero sus fibras son más moles y no tan susceptibles de endurecerse, como es característico de la vejez. Pero, según Hufeland, los hombres tienen ventajas sobre las mujeres por la superioridad de fuerzas.

Luego de analizar los cambios físico y algunos fisiológicos que se producen con la vejez, pasa a ocuparse de las medidas propiamente higiénicas, analizando - a modo de las topografías médicas de la época - las relativas al domicilio, el clima, el ambiente en general, alimentación, sueño, ejercicio, aseo y otras.

Es típica, por ejemplo la valoración de la influencia del clima en la duración de la vida o la producción de enfermedades y epidemias, muy relacionadas con las condiciones geográficas (ya presentes en los antiguos galenos, en efecto se cita aquí a Plinio, aunque también a Bacon), como la situación más o menos elevada, la proximidad del agua, atmósfera, vida en islas o continentes, etc. Así, en cuanto al clima, se asegura que los habitantes de los países calurosos, si bien gozan de buena salud y suelen ser longevos, tienen una vida muy acelerada, las mujeres son madres a una edad muy temprana, los alimentos son poco fortificantes y sus pasiones ardientes; estas causas tienden a limitar la duración de la existencia. Pero en general los climas calurosos, son más favorables para la salud, que para la longevidad; y al contrario, los fríos. 
Muy predominante en la época es la teoría de los miasmas como agentes productores de enfermedades y epidemias. Todavía Pasteur no había realizado sus famosos trabajos, ni Finlay había planteado su teoría sobre la transmisión de la fiebre amarilla por el mosquito. Pero en este caso, las fuentes son bastantes atrasadas, remitiéndose a Bacon. Así se atribuye a los gases y a la putrefacción orgánica - ni siquiera a los llamados micrófitos u otros agentes, de los que se habla en ocasiones, si bien más a menudo a partir de la década del setenta decimonónico ${ }^{19}$ - , asegura que los terrenos pantanosos son malsanos a causa de las exhalaciones producidas por el gas carbónico, que las lagunas, según Bacon, son más perniciosas para los extranjeros que para los nacidos en el país; que las proximidades de las mareas a esos lagos y pantanos, son más perjudiciales porque traen gran número de insectos y peces que, al pudrirse, hacen pestilífero el aire; que las islas son más saludables que los continentes, y que se han de tomar ciertas precauciones que impidan la indolencia en un clima frío o caluroso.

En relación con todo este asunto es interesante también, por ejemplo, la idea - bastante antigua ya - de que no viven más los opulentos que los que llevan una vida moderada, haciendo ejercicio al aire libre; el papel de la educación y la moral para vigilar la salud, pasatiempos, y ciertas profesiones como la agricultura, ocupación no muy violenta, por lo que los agrónomos llegan a una edad avanzada. Siguen en orden de importancia las manufacturas y artes mecánicas, pero el uso de ciertos materiales y maquinarias despiden miasmas deletéreos, perjudiciales sobre todo en talleres poco ventilados, por lo que se deben poner estos talleres en las campiñas. Algo parecido sucede con las minas, pues los mineros se encuentran expuestos a emanaciones de azufre, plomo, mercurio, pero gracias al régimen que se lleva en la mayor parte y a las precauciones que se toman, los mineros son gente robusta y bien constituida.

En general las fuentes que utiliza el autor son bastante atrasadas, y quizá lo más moderno e interesante sea el análisis del aire (sus propiedades físicas y químicas) en relación con la salud y la duración de la vida, donde se citan los trabajos realizados por Alejandro de Humboldt y por Gay-Lussac, o al hablar de la naturaleza del terreno, donde se citan entre otros a Dudley, Baker, Kirkland. Si bien siempre se acepta que el aire es capaz de corromperse llegando a matar animales, como sucede en cuevas subterráneas y pozos viejos.

19 Véase, por ejemplo, «El cólera, su causa y la de otras enfermedades contagiosas considerada en la ozona y los micrófitos, por el Dr. Cook, A. Muller», Anales de la Real Academia de Ciencias Médicas, Físicas y Naturales de la Habana, 7, 1870, pp. 243-245. 
Lo malsano de las aguas en ese sentido, y de otros líquidos como el café, el té, el chocolate, son analizados por el autor. Las frecuentes adulteraciones que se producían por entonces y que son recogidas por todos los manuales de higiene al uso, es preocupación constante de médicos y autoridades. Es curiosa la alusión aquí de un producto inventado por Hahnemann - el creador de la homeopatía, cuyos trabajos Pusalgas llegó a conocer, como cita en otras memorias - por medio del cual se podía conocer estas falsificaciones, y que estaba constituido por agua y 16 gramos de hígado de azufre seco (sulfato de potasa), entre otros componentes.

La higiene es concebida en este trabajo como parte de una concepción mecanicista del cuerpo humano, en que los delicados órganos cumplen leyes relacionadas, de modo que cualquier desequilibrio en uno de ellos, pasa al otro, produciendo un desarreglo general. Cumpliendo los cánones de la higiene se aseguraba ese equilibrio y con ello la duración larga de la vida.

\section{EL CÓLERA}

Pusalgas tuvo la oportunidad de observar y, en cierta medida participar, en dos de las grandes epidemias de cólera morbo que asolaron España durante el siglo XIX: la de 1834 y la de 1854. En la primera de ellas recogió diversas notas que, según expresa no llego a publicar, mientras que de la segunda aglutinó sus opiniones en un compendio ${ }^{20}$, que publicó en 1855. Durante esta última epidemia, se había presentado en el pueblo de Masnou, con su familia, el 5 de agosto, e hizo allí observaciones médicas y prestó sus conocimientos a la «humanidad doliente, sin retribución ni honorario alguno».

A modo de las topografías médicas de la época, destaca la relación entre las condiciones sociales, políticas, geográficas e higiénicas con las enfermedades y epidemias. En ese sentido refiere el estado en que se encontraba Barcelona y los demás pueblos y ciudades de España, bajo un "régimen extremadamente rígido» que exigía enormes impuestos y quitaba dignidades y empleos. El sufrimiento producido por estas cuotas injustas, el allanamiento de casas y la venta de sus muebles en pública subasta provocaba ataques apopléticos y convulsiones nerviosas, y el propio Pusalgas fue llamado entre otros para atender algunos de estos casos. Odier y Sarlandiere en su memoria

20 Pusalgas, I. (1855), Cólera en 1854: historia descriptiva y médica del cólera morbo epidémico, que invadió la ciudad de Barcelona y pueblos de su provincia, Barcelona, Viuda de Saurí e Hijo. 
sobre la higiene, también hablaban de revoluciones políticas, vejaciones, guerras y persecuciones, como causas poderosas de muchas enfermedades.

Los hechos acaecidos en Barcelona, el 14 y 15 de julio de 1854 - con motivo del alzamiento en Torrejón de Ardoz de los generales O'Donnell y Dulce el 28 de junio - en que «gente plebeya» atacaba las propiedades de las personas pacíficas, con el puñal y la tea incendiaria, había provocado gran temor, y sin ese temor el cólera no habría hecho tantos estragos como hizo «en la ciudad de nuestra cuna», dice Pusalgas, quien estimaba que el terror y el temor eran causas predisponentes y ocasionales del cólera morbo epidémico.

A eso había que añadir - aseguraba - que Barcelona era una verdadera madriguera, con pocos espacios para respirar, exceptuando los paseos de la Explanada y la Rambla, pues abundaban las casas mezquinas, se sustituían las huertas por edificios, plazas y mercados, las fábricas hacían impuro el aire. Si bien - y aquí destacaba las muchas ofertas que se brindan en la ciudad: educativas, alimentarias, de beneficencia - los contornos de la ciudad eran amenos y deliciosos, con pueblos y quintas que formaban un jardín encantador.

En estado normal, las enfermedades que más abundan en Barcelona eran las inflamaciones, catarros de invierno, erupciones cutáneas, algunas intermitentes, diarreas en verano; y en todas las estaciones, la tisis, las fiebres tifoideas - de carácter adinámico en los hombres y de atáxico en mujeres- calenturas exantemáticas propias de la infancia, viruelas, sarampión, escarlatina y rubeola. Aunque las calenturas mesentéricas eran, en ocasiones, epidémicas.

En la época de Pusalgas no se conocía el agente causal del cólera (los vibriones que se transmiten con el agua), de modo que se ve precisado a reconocer que se desconoce el verdadero origen de la enfermedad, a pesar de los análisis químicos y físicos de la atmósfera, el modo de vivir de las personas, sus costumbres y calamidades. Pero Pusalgas ve en este velo sobre los ojos una causa para admirar el poder de Dios. Está claro que él no hizo autopsias ni inspeccionó los cadáveres. Por esa razón destaca más las cuestiones morales y sociales e higiénicas, como causas coadyuvantes a la enfermedad.

Así expresa que la posición geográfica de Barcelona es ventajosa en general para la salud de sus habitantes, pero el temor, el sobresalto, las pasiones deprimentes, la soledad de los enfermos abandonados por familiares, los pueblos por funcionarios y eclesiásticos, eran factores que favorecían el cólera. A ello se añadían las condiciones malsanas de la clase pobre: reducidas habitaciones, hacinamiento, humedad, falta de higiene, uso inadecuado de ropas, mala alimentación, excesivo trabajo, falta de educación e inmoralidad. Entre líneas, la crítica social cuando se pregunta, por ejemplo, cómo tienen tiempo de aparejar una buena comida las clases proletarias si trabajan doce horas al 
día. Y también su acendrada convicción religiosa: las pocas víctimas del cólera en los conventos religiosos donde se lleva un régimen morigerado, en contraposición con el resto de la ciudad.

En su memoria, recoge los casos de enfermos en diversos establecimientos, estadísticas, mediciones meteorológicas, la situación de varios pueblos y ciudades durante la epidemia, así como las medidas tomadas por el Ayuntamiento Constitucional y por la Comisión Permanente de Sanidad, dividiendo en demarcaciones a Cataluña, y nombrándose después facultativos por barrios para atender mejor a los enfermos. En este proceso Pusalgas debió sentirse relegado, pues dice sentir en el alma que se hubieran colocado en las 28 demarcaciones médicos jóvenes, que si bien tenían talento y aplicación, no fueran acompañados o sustituidos por «profesores aguerridos con el enemigo colérico», de que no carecía el claustro de la Universidad, la Academia de Medicina y Cirugía y toda la capital.

De todas formas, poco podían hacer los médicos ignorando el verdadero agente causal de la enfermedad. El propio Pusalgas afirma que los métodos curativos que se pusieron en práctica por los distintos facultativos fueron tan varios que podía decirse que cada uno tenía el suyo. Si bien debieron ser los tradicionales, pues al decir del médico barcelonés, no creía se hubieran aplicado los baños recomendados por Recamier, el magnetismo, la electricidad, la acupuntura y la electropuntura que se aplicaban en el Hospital de Dios en París. En cambio, abundaron los remedios milagrosos y absurdos propuestos por charlatanes, interesados y hasta por los propios enfermos. Los anuncios frecuentes que se publicaban en los periódicos, requirieron de la intervención del gobierno de Cataluña, prohibiéndolos.

La situación debió ser espantosa según se desprende de esta memoria de Pusalgas, que analiza no sólo la situación de Barcelona, sino de otros pueblos de Cataluña. Así cree que, aunque la capital contó con buenas medidas sanitarias y suficiente número de médicos, no sucedió lo mismo con los pueblos. Por ejemplo, Masnou, desde el 5 de agosto hasta primeros de septiembre sólo tuvo un médico; los enfermos de Montgat curaban o se morían sin una visita de éste. Tampoco los coléricos de Mataró tuvieron médico en los primeros días de la epidemia. La mortandad era grande y los sucesos traumáticos. En este último pueblo, los cadáveres eran transportados en dos carros amortajados unos, en ataúdes otros, a pleno mediodía. Lo que motivó que el pueblo se amotinase por la hora tan intempestiva en que eran trasladados. Ello requirió de la intervención del gobernador Pascual Madoz y del vocal de la Junta de Sanidad, José Viñolas. La violencia de la enfermedad, hizo que la gente acudiera a recibir los santos sacramentos, ante el temor de morir repentinamente. 
Pero fue mayor el terror cuando hallaron en la puerta principal de la parroquia, un montón de cadáveres, depositados allí para darles luego sepultura.

El plan de medidas y acciones, elaborado por Madoz y la Junta de Sanidad, para contrarrestar la epidemia abarcaba no sólo las administrativas e higiénico-sanitarias, sino también otras que se referían a las necesidades de los hospitales provinciales y provisionales. Algunas de esas medidas, tenían que ver con los efectos de la enfermedad, y en especial con los vómitos y diarreas, pues se recomendaban no comer cosas indigestas, que incluían frutas verdes, tomates, pimientos, coles y otras verduras flatulentas; ciertos líquidos, como la leche, o sorbetes y helados. Otras estaban acordes con la omnipresente teoría de los miasmas, como agentes productores de enfermedades: No respirar el aire impuro de ciertas localidades peligrosas. Y otras con la imprudencia: No desafiar neciamente el mal con balandronadas y desarreglos.

A pesar de todo ello, ningún remedio fue efectivo en la curación del cólera, acepta Pusalgas, quien además refiere las dudas existentes en los profesores sobre si el cólera morbo era o no contagioso, recogiendo la opinión de los que como Depech entendían que esta enfermedad se hacía contagiosa cuando su foco era grande y poderoso. Pero se pregunta, si tantos puntos atacados y en diferentes distancias se convertían en focos transportados por personas salidas de los lugares infectos. Como no se sabía el verdadero origen de la enfermedad, el propio Pusalgas se cuestionaba también si para el desarrollo de esta epidemia era necesaria una causa mórbida que permaneciera oculta en el cuerpo, incubada, como sucedía en todo contagio. Los debates en torno a si era o no contagiosa, se habían producido en la Academia de Medicina de Barcelona en 1834. La confusión estribaba en que aparecía en distintas regiones, por el hecho de que algunos de los que huían de una ciudad a otra podían ser portadores de la misma porque ya la padecían.

En cuanto a la acción atmosférica, si bien Pusalgas concedía que algunas indicaciones barométricas y termométricas tenían relación con enfermedades esporádicas y epidémicas, creía que muy poco se podía atribuir a las afecciones meteorológicas como causas poderosas del cólera. Para él, el tiempo quizá señalaría como causa conjunta de tal enfermedad, «el ozono u otra combinación del fluido eléctrico con los demás cuerpos de la atmósfera, tanto ponderables como imponderables».

Al final, el Ayuntamiento Constitucional de Barcelona homenajeó a Madoz, por su actuación ante la epidemia colérica, dedicándole Pusalgas un soneto que reproduce en su trabajo, y que es una muestra más de sus inquietudes literarias. 


\section{RELIGIÓN, MORAL E HIGIENE}

Como se ha visto hasta aquí, la interrelación de estos tres aspectos como productores de la felicidad, la salud y la duración de la vida de los seres humanos, es frecuente en las obras del médico barcelonés. Hombre profundamente religioso, lo reflejó también en otras obras suyas ${ }^{21}$. A modo de muestra, nos referiremos en esta ocasión a su Discurso sobre la Religión, la Moral y la Higiene..., publicado su ciudad natal en 1857. Aquí, destaca la parte inmaterial creada por Dios, que distingue al hombre de los animales. Pero tanto éste como aquellos con sus instintos, son guiados hacia el amor, la conservación de la salud y la prolongación de sus vidas, guardando limpieza en el baño, al beber aguas limpias, construir nidos y guaridas limpias, etc. Sin el concurso de la religión, la historia natural y la higiene no sirven de nada. No obstante, a pesar de estos sanos preceptos, se ven hombres que menosprecian esos consejos y reglas de la higiene, de la moral y de la religión «con la suciedad más asquerosa, con los vicios más torpes y el desprecio de las cosas más santas y saludables». El hombre es el único eslabón que une a las demás criaturas con los ángeles y está hecho a imagen de su Creador.

La religión atempera la cólera, el malhumor, los celos, la pereza, la relajación de las costumbres, origen de tantos males. El temor de ser castigado por Dios y los preceptos de la religión se convierten en saludables consejos higiénicos, evitando la apoplejía fulminante en el colérico, la calentura gástrica en el glotón y el ataque convulsivo o el homicidio de un negativo. La religión sirve también para prevenir enfermedades morales como el onanismo. Esta muestra de la «viciosa e inexperta juventud», se confiesa - según su experiencia: 23 años en la medicina - primero al sacerdote antes que al médico. Pudor y vergüenza que son obstáculos para el médico a la hora de formar un acertado pronóstico de ciertas enfermedades y vicios vergonzosos. Por otra parte, las funestas consecuencias de este mal, tratadas en sus obras por Tissot, Debreyne y otros galenos reputados, no están alcance de los jóvenes.

La religión preserva contra este pecado capital, así como contra la prostitución -úlcera gangrenosa, como dice su discípulo Felipe Monlau en su obra sobre higiene - de la gula, los virus de las pasiones, juegos de azar, ociosidad, lectura de libros obscenos, produciendo en cambio un efecto bienhechor la fe, la esperanza y la caridad, como se ve en las obras de Hipócrates y Boer-

21 Pusalgas, I. (1857), Discurso sobre la religión, la moral y la higiene como inseparables hermanas que de consuno procuran la felicidad del hombre: leido en la Universidad Central en el acto... de recibir la investidura de doctor, Madrid, Imprenta F. Sánchez. 
have. La religión también evita los estragos de la guerra, «y sólo la permite cuando es defensiva para sostener los sagrados derechos de la Patria y de la ley de Dios». Y aconseja a los príncipes que en lugar de emplear la fuerza, traten sus intereses con la justicia y la razón.

La religión y la higiene detienen al panadero para que no emplee harina de mala calidad, la lechera no eche agua a la leche, el traficante de vinos no use productos químicos para colorear o endulzar sus bebidas, con efectos tóxicos. El desprecio a estos preceptos es posible observarlo en el cuadro estadístico de Francia, durante el periodo de su revolución e incredulidad, y de España, imperando «los funestos partidos a los que acompañan el desprecio de las cosas santas y la desmoralización», en que el número de homicidios y suicidios es imponderablemente mayor que en tiempos de calma y confianza.

El código moral mediante sus leyes premia la virtud y castiga al vicio, las mismas virtudes que ensalza la religión y la higiene para conservar la salud, al tiempo que castiga los delitos, los vicios y los efectos trascendentales en detrimento del bienestar de las personas. En una nación sin religión ni moral, la venganza se sacia, al avaro amontona dinero sin conciencia y el comerciante engaña. Sin moral no valen las leyes fundamentales, no son obedecidos los bandos del gobierno, y se hace sentir a menudo el azote de las epidemias y los contagios.

Las facultades propias del alma le dotan para estudiar su naturaleza y evitar cuanto le es perjudicial. Así, la moral dice a los de temperamento sanguíneo y bilioso que no sean coléricos; a los de temperamento nervioso y sensible, que se fortifiquen y robustezcan con la voluntad y el ejercicio del cuerpo para llegar a ser más saludables y longevos.

La higiene pública y privada da preceptos a los gobiernos, corporaciones y grupos de individuos, para preservar la salud del hombre. Siguiendo los mismos preceptos que la religión y la moral, da reglas (ejercicios corporales, limpieza, calidad de alimentos y bebidas, ropas) para evitar los desconocidos gérmenes de muchos contagios y epidemias.

La relación de sus ideas religiosas con la naturaleza, las dejó bien claras en un tratadito que publicó en 1854. En cuanto a los aspectos morales dentro de su concepción católica, Pusalgas escribió dos obras, unas Lecciones de moral, y unos Cuentos morales para niños, publicados en Barcelona en 1839 y 1844 , respectivamente 22 .

22 Pusalgas, I. (1844), Cuentos morales para niños, Barcelona; Pusalgas, I. (1854), La existencia de Dios por las obras de la naturaleza, Barcelona; PUSALGAS, I. (1839), Lecciones de moral, ó sean, Preceptos de un buen padre á sus hijos, Barcelona, Imprenta de Indar. 


\section{CIENCIA E HISTORIA}

La afición de Pusalgas por la historia tiene dos muestras fehacientes: su traducción libre de la Historia de París, de Eugêne de Monclave ${ }^{23}$, y su tratado sobre los acontecimientos políticos y sociales ocurridos en Barcelona durante el alzamiento de la Junta general contra Espartero ${ }^{24}$. En esta se refleja la posición conservadora de Pusalgas, que lo criticó desfavorablemente desde varios puntos de vista, incluyendo el religioso y médico-higienista. Así, vio a los ocupantes de la ciudad como «una turba insolente de hombres sin moral ni religión» que lo destruían todo insultando y menospreciando santuarios divinos, arte y ciencia. Individuos cuyos rostros y corazones eran dignos de las pinturas de frenólogos, fisionomistas y fisiologistas como Gall, Lavater y Alibert.

Además de considerar a las tropas revolucionarias como un bando de facinerosos sin orden ni disciplina, compuesto por presidiarios, criminales salidos de las cárceles públicas, de casas de corrección, de gitanos, viejos e imberbes, cojos, corcovados, en fin, escombros de la sociedad procedentes de varias ciudades, Pusalgas subraya los efectos desastrosos que tuvo para la higiene de la ciudad. Describe que la plaza era un muladar de excrementos, que se veían a los invasores como "animales inmundos» tendidos en ella, haciendo aguas mayores por todas partes, mientras que los cadáveres de animales domésticos despedían hedor insoportable, sin que las autoridades municipales tomasen medidas para asegurar la salubridad pública, siendo un milagro de la Providencia que no se desatasen epidemias y enfermedades.

Como recorrió la ciudad para ver los efectos producidos por las tropas revolucionarias, visitando especialmente iglesias y hospitales, Pusalgas dice entre otras cosas que los hospitales civil y militar estaban destinados para recibir a los heridos centralistas, el de Junquera y el Seminario recibían los de las partidas sueltas, y el de Santa Cruz a los milicianos. Pero como muchos de los médicos de esos establecimientos se habían ausentado, la administración general de los hospitales se vio obligada a no admitir otros enfermos, si no venían acompañados de una certificación médica que probase su dolencia y pobreza.

23 Monclave, E. de (1838), Historia de París por Eugenio de Monclave (traducción de Ignacio Pusalgas), Barcelona, Imprenta de Oliveros y Gavarró.

24 Pusalgas, I. (1843), Acontecimientos politicos e históricos de Barcelona desde el 2 de septiembre de 1843 hasta la entrada de las tropas nacionales con las medidas oportunas que tomó el gobierno militar después de haber entrado en el goce de sus derechos, por unos literatos que permanecieron en ella durante aquella desgraciada temporada D. y P. y D.P.G., Barcelona, Imp. Ramón M. Indar. 


\section{CIENCIA Y LITERATURA}

Pusalgas reflejó sus conocimientos científicos en las dos novelas ya mencionadas $^{25}$. Sin entrar en muchos detalles, diremos que, escritas siguiendo la más pura corriente romántica, no faltan en ellas los recursos que se emplearon en esa clase de obras (desmayos, misterios, virtud exaltada, enseñanzas morales y hasta lances y duelos al estilo de las novelas de caballería). Sin embargo, resultan interesantes. Los personajes se interrelacionan bien, describen y cuentan sus vicisitudes, en medio de una trama histórica, desgraciadamente poco ajustada a la realidad, a pesar de que en ambas novelas, el autor consultó diversas obras de los Cronistas y de otros autores.

Ubicada una durante el descubrimiento y conquista de Cuba, y de México la otra, Colón y sus hijos, Cortés y Moctezuma, desempeñan un papel sobresaliente en estas novelas, donde abundan las tramas amorosas, los crímenes, y suicidios, pero también aventuras y romances, y donde los indios hablan, sienten y se comportan psicológicamente como los europeos. Hombre, muy católico y conservador, como ya se ha dicho, su religión es adquirida por algunos personajes (por lo general los simpáticos y buenos), está siempre presente y es la solución para evitar el concubinato, espiar los pecados de muchos de ellos o para contraponerla a la bárbara religión de los indios con sacrificios humanos, adoración al sol, a los árboles y otras muestras de idolatría. Eso hace que describa las chozas de los indios con puertas, que los baños para hombres y mujeres, estén separados, o se vean las relaciones sexuales y el embarazo como algo pecaminoso y otras manifestaciones morales, más propias de europeos que de aborígenes.

Del mismo modo, se agregan disertaciones políticas por las cuales habla Pusalgas en contra de tiranos, gobernadores, déspotas y caciques que no conducen bien a sus pueblos, los cargan de impuestos o no le dan educación suficiente. No cabe duda de que la obra de este médico barcelonés es una parábola de la España de su tiempo ${ }^{26}$. La visión rosseauniana - autor al que cita en su obra sobre México - explica su disertación, en boca de varios personajes, contra el despotismo y la esclavitud, así como sobre «la razón y el tiempo y

25 Pusalgas, I. (1988), El Nigromántico mexicano, Sabadell, Caballo Dragón, D. L. (Colección Los Inenarrables, 3), reimpresión de 1838; PusAlgAS, I. (1839), El sacerdote blanco, o la familia de uno de los últimos caciques de la isla de Cuba: novela histórica americana del siglo décimo quinto, Barcelona, Imprenta de Indar, 2 t.

26 Esto es algo que se pregunta el comentarista de la segunda edición de El Nigromántico Mexicano, o cuando sugiere al lector que lea en lugar del nombre de Moctezuma, el de Fernando VII. 
no la violencia y la autoridad son las que pueden producir útiles revoluciones», mientras que los legisladores deben procurar mantener a su país en la abundancia y paz, haciéndola superior a los demás con sabiduría, virtudes y felicidad. En ese sentido, se encamina la oración inaugural de Cortés, al final de la novela mexicana llamando a las leyes naturales, la obediencia, la moral, la ley social, los derechos, las leyes religiosas y los deberes del soberano en contra de los estados despóticos. A pesar de que Pusalgas manifiesta también que el vencedor no tiene derecho a esclavizar al vencido, su opinión está a favor de la conquista y la colonización en todo tiempo. Lo que explica su crítica final a los países americanos que se habían liberado o pretendían exonerarse, para formar gobiernos a su antojo y habían caído en «el horroroso abismo de las disensiones intestinas y guerras extranjeras, o al tratamiento más bárbaro que han elegido para ser gobernados».

En cuanto al aspecto científico, en ambas novelas se introducen plantas y animales que no son propios de América. Así, por ejemplo, en Cuba y México menciona árboles, como el boabad, asbesto, dracaenias, adamsonias, rafflasias y otras plantas de las que describe sus características y utilidades desde los tiempos antiguos, pero que son de Sumatra, Ceilán u otras regiones del mundo. Introduce en la isla fieras como leones y tigres, que acompañan al sacerdote blanco o persigue a los indios. Otras veces, simplemente menciona que las especies se parecen a varias de España o de Europa. Además de los Cronistas de Indias, son citados diversos autores, que revelan sus muchas lecturas, entre los que se cuentan Marco Polo, Alejandro de Humboldt, Parisot y otros. Las notas a pie de página le sirven para describir geográficamente la flora y fauna de ambos países, fenómenos físicos y otras cuestiones científicas.

La descripción física que hace de los indios en ambas novelas es por regular favorable, destacando la gran belleza de las indias, si bien en ocasiones con rasgos europeos, como cuando dice por ejemplo que la hija de Moctezuma tenía las mejillas encarnadas y los ojos azules.

Pusalgas no puede menos, como médico al fin, que referirse a la forma de curar las heridas, con plantas por parte de los indios, de describir la locura o monomanías de algunos personajes, los paroxismos y momentos finales de otros, el tratamiento mediante manantiales de aguas medicinales y baños públicos promovidos por caciques o marcas hereditarias que explica con razones fisiológicas en oposición a las creencias vulgares. Asimismo, recoge algunas manifestaciones de enfermedades como la viruela que asoló a las poblaciones aborígenes, $\mathrm{o}$, como ya sabemos, subraya la significación de impresiones emocionales y morales en la afectación de la salud y hasta de la pérdida de la vida.

En sentido general, Pusalgas se enmarca dentro de un período signado por convulsos movimientos políticos e históricos de España y de su ciudad natal, 
Barcelona, pero también pudo constatar las pugnas que se dieron entre médicos y cirujanos, entre el Colegio y la Universidad, y entre los mismos profesionales por alcanzar notoriedad. Intentó conciliar sus opiniones científicas y literarias con su profunda raigambre religiosa. En el terreno científico defendió algunas corrientes que eran controvertibles y hasta negadas por los científicos más avanzados, como eran la frenología y la fisiognomía de Gall y Lavater respectivamente, pero que todavía tenían mucha aceptación. En sus obras perduran aún vetas mecanicistas y vitalistas, y pueden encontrarse además referencias a la homeopatía muy difundidas en esa época. En gran medida son el resultado de las fuentes - sobre todo francesas - que empleó para elaborar sus trabajos. Del mismo modo que puede observarse en las realizadas por otros autores españoles, como Manuel Hurtado de Mendoza, Agapito Zuriaga, Lorenzo Boscasa o Mariano López Mateos, por sólo mencionar algunos. Pero en estos, como en el propio Pusalgas, la intención era hacer más accesibles a los estudiantes los conocimientos áridos de la anatomía. Su entrega a la docencia durante la mayor parte de su vida, merece reconocimiento, de la misma manera que un lugar dentro de la cultura hispana. 